\title{
SISTEM INFORMASI SELEKSI PENERIMAAN BEASISWA PTN SISWA/I LABUHANBATU BERBASIS WEB
}

\author{
Rita Yunida ${ }^{1)}$ Ronal Watrianthos ${ }^{2)}$ Marnis Nasution ${ }^{3)}$ \\ ${ }^{1,2.3)}$ Akademi Manajemen Informatika Komputer Labuhan Batu \\ Jalan SM Raja No. 126 Km. 3.5 Aek Tapa Rantauprapat \\ ritayunida26@gmail.com ${ }^{1)}$, mail.to.ronal@gmail.com ${ }^{2)}$, nenis@ yahoo.com ${ }^{3)}$
}

\begin{abstract}
ABSTRAK
Adapun Penulisan Tugas Akhir ini bertujuan untuk merancang suatu Sistem Informasi. Sistem ini nantinya diharapkan dapat mempermudah pendaftaran beasiswa PTN, dan mampu mengerjakan tugas dengan tepat dan cermat dalam pengambilan keputusan pada Kantor Kesra Setdakab Labuhanbatu Rantauprapat. Sekaligus sebagai salah satu syarat untuk menempuh Ujian Sidang Tugas Akhir Pada Akademi Manajemen Informatika Komputer (AMIK) Labuhan Batu. Adapun Bahasa Pemograman yang digunakan dalam pembuatan Sistem yang dimaksud adalah Menggunakan PHP dan MySQL. Aplikasi Pembuatan databasenya menggunakan MySQL dan Server Appserv, Localhost Phpmyadmin. Penyusunan Tugas Akhir ini dimulai dengan Merumuskan masalah, Mengidentifikasi masalah, Penentuan Tujuan dan Manfaat dan Mengumpulkan data tentang Sejarah berdirinya Instansi. Setelah semua data yang di butuhkan di dapatkan, maka dilanjutkan ke Proses Analisis Sistem. Hasil dari pembuatan program yakni ditujukan dengan Terselesaikannya Sistem Informasi Seleksi Penerimaan Beasiswa PTN Labuhanbatu Berbasis Web. Semoga dengan adanya sistem informasi ini, dapat meningkatkan Kinerja dalam proses pendaftaran dan pencarian data Beasiswa PTN Siswa/i Labuhanbatu Rantauprapat.
\end{abstract}

\section{Kata kunci : Sistem Seleksi Penerimaan Beasiswa PTN Siswa/i Labuhanbatu Berbasis Web, MySQL, Appserv}

\begin{abstract}
The writing of this Final Project aims to design an Information System. This system is expected to facilitate the registration of PTN scholarship, and able to perform the tasks accurately and carefully in decision making at the Office of Welfare Setdakab Labuhanbatu Rantauprapat. Simultaneously as one of the requirements to take the Examination Trial Final Tests At Computer Information Management Academy (AMIK) Labuhan Batu. The programming language used in making the System in question is Using PHP and MySQL. Application Database creation using MySQL and Appserv Server, Localhost Phpmyadmin. Preparation of this Final Project begins by formulating the problem, Identifying problems, Determination of Objectives and Benefits and Collecting data on the History of the establishment of the Agency. After all the data needed in get, then proceed to Process System Analysis. The result of the program making is aimed at the completion of the Selection Information System of PTN Labuhanbatu Web-Based Scholarship Reception. Hopefully with this information system, can improve Performance in the process of registration and search data PTN Student Scholarship / Labuhanbatu Rantauprapat.
\end{abstract}

Keywords: Admissions Selection System PTN Student / i Labuhanbatu Web Based, MySQL, Appserv 


\section{PENDAHULUAN}

Seiring perkembangan teknologi informasi yang semakin pesat mempengaruhi suatu sistem informasi mendukung kebutuhan instansi terutama instansi pemerintahan dalam rangka menciptakan efisiensi operaisonal dan efktifitas dunia kerja maupun dalam meningkatkan pelayanan kepada masyarakat. Apalagi pengolahan dan penyimpanan data sangat penting dimiliki oleh suatu instansi yang perlu ditangani secara komputerisasi, agar pekerjaan lebih efektif ataupun mencapai tujuan yang diharapkan.

Dalam era globalisasi ini, komputer merupakan salah satu alat yang sangat dibutuhkan banyak pihak dan telah membuka peluang seluasnya kepada para pakar dan para pengambil keputusan, baik dari instansi perusahaan pemerintah maupun swasta untuk menyelesaikan semua permasalahannya dengan menggunakan komputer. Saat ini komputer berperan aktif dalam segala bidang sehingga dengan adanya komputer akan sangat membantu dalam penyajian data yang akurat, cepat, dan tepat.

Kantor Kesra Setdakab Labuhanbatu adalah instansi yang bergerak dalam bidang pendataan Beasiswa PTN bagi siswa/siswi Labuhanbatu. Berdasarkan Peraturan Bupati Labuhanbatu Nomor 7 Tahun 2013 tentang pedoman pemberian Beasiswa bagi mahasiswa kabupaten Labuhanbatu bahwa guna meningkatkan akses dan kesempatan belajar di universitas Negeri maka perlu dilakukan Pemberian beasiswa mahasiswa dimaksudkan untuk meningkatkan kualitas sumber daya manusia guna percepatan pembangunan di Kabupaten Labuhanbatu.

Oleh sebab itu untuk mempermudah proses verifikasi pendataan beasiswa perlu dibuatnya sistem yang terkomputerisasi maka penulis membuat sebuah sistem informasi yang dapat menyelesaikan masalah yang dihadapi oleh kantor kesra setdakab dengan membuat penelitian tugas akhir yang berjudul "SISTEM INFORMASI SELEKSI PENERIMAAN BEASISWA PTN SISWA/I LABUHANBATU BERBASIS WEB“.

\section{TINJAUAN PUSTAKA 2.1 Pengertian Sistem Informasi}

Menurut Tata Sutabri (2017) "Informasi adalah data yang telah diklasifikasi atau diinterpretasi untuk digunakan dalam proses pengambilan keputusan". Menurut Tata Sutabri (2017) "Sistem informasi adalah suatu sistem di dalam suatu organisasi yang mempertemukan kebutuhan pengolahan transaksi harian yang mendukung fungsi operasi organisasi yang bersifat manajerial dengan kegiatan strategi dari suatu organisasi untuk dapat menyediakan kepada pihak luar tertentu dengan laporan laporan diperlukan". Menurut Al-Bahra Bin Ladjamudin (2017) "Sistem informasi adalah suatu yang dibuat oleh manusia yang terdiri dari komponen-komponen dalam organisasi untuk mencapai suatu tujuan yaitu menyajikan informasi”.

\subsection{Pengertian Beasiswa}

Menurut Dedi Achmad Sidik (2015), Beasiswa dapat dikatakan sebagai pembiayaan yang tidak bersumber dari pendanaan sendiri atau orang tua, akan tetapi diberikan oleh pemerintah, perusahaan swasta, kedutaan, universitas, serta lembaga pendidik atau peneliti, atau juga dari kantor tempat bekerja yang karena prestasi seorang karyawan dapat diberikan kesempatan untuk meningkatkan kapasitas sumber daya manusianya melalui pendidikan. Biaya tersebut diberikan kepada yang berhak menerima, terutama berdasarkan klasifikasi, kualitas, dan kompetensi si penerima beasiswa.

\subsubsection{Siklus Informasi}

Menurut Al-Bahra Bin Ladjamudin (2017), Untuk memperoleh informasi yang bermanfaat bagi penerimana, perlu untuk dijelaskan bagaimana siklus yang terjadi atau dibutuhkan dalam menghasilkan informasi. Siklus informasi atau siklus pengolahan data adalah sebagai berikut.

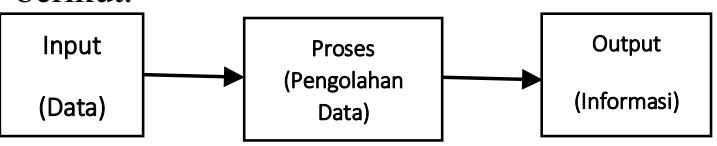

\subsection{Konsep Basis Data}

\subsubsection{Defenisi Basis Data}

Menurut Yuhendra, M.T, Dr. Eng (2015), Database adalah kumpulan data yang saling berhubungan (relasi). Istilah tersebut bisa digunakan pada sistem-sistem yang terkomputerisasi. Dalam pengertian umum, 
database diartikan sebagai gabungan dari elemen-eleman data yang berhubungan dengan teroganisir.

Menurut Akhmad Sholikhin (2013), Basis data sendiri dapat didefinisikan dari beberapa sudut pandang yang ada seperti:

1. Himpunan kelompok data (arsip) yang saling berhubungan dengan diorganisasi sedemikian rupa agar kelak dimamfaatkan kembali dengan cepat dan mudah.

2. Kumpulkan data yang saling berhubungan yangdisimpan secara bersama sedemikian rupa dan tanpa pengulangan (redudansi) yang tidak

3. perlu, untuk memenuhi sebagai kebutuhan Kumpulan file /table/ arsip yang saling berhubungan yang disimpan dalam media penyimpanan elektronik.

\subsubsection{Tujuan Basis Data}

Tujuan utama dari pemamfaatan basis data dalam pengolahan data adalah:

1. Kecepatan dan Kemudahan (Speed) Pemamfaatan basis data memungkinkan kita untuk dapat menyimpan data atau melakukan perubahan atau manipulasi terhadap data atau menampilkan kembaki data tersebut dengan lebih cepat dan mudah, daripada jika kita menyimpan data secara manual (non elektronis) atau secara elektronis (tetapi tidak dalam bentuk penerapan basis data missalnya dalam bentuk spread sheet atau dokumen teks biasa).

2. Efisiensi Ruang Penyimpanan (space)

Karena keterkaitan yang erat data dalam sebuah basis data, maka redudansi data pasti terjadi. Banyaknaya redudansi ini tentu akan memperbesar ruang penyimpanan yang disediakan. Dengan basis data, efisiensi atau optimalisasi penggunaan ruang penyimpanan dapat dilakukan, karena kita dapat melakukan penekanan jumlah redudansi data, baik atau dengan menerapkan sejumlah aturan dalam pengkodean atau dengan membuat relasirelasi antar kelompok antar data dan saling berhubungan.

3. Keakuratan (Accurancy)
Pemanfaatan pengkodean atau pembentukan relasi antar data bersama dengan penerapan aturan atau batasan (constraint) tipe data, domain data, keunikan data dan sebagainya sangat berguna untuk menekan ketidakakuratan pemasukan atau penyimpanan data.

4. Ketersediaan (Availability)

Data akan selalu siap dibutuhkan jika sewaktu - waktu akan di butuhkan atau digunakan.

5. Kelngkapan (Completeness)

Kelengkapan data menyimpan struktur yang mendefinisi detail dari tiap objek sehingga kita dapat melakukan perubahan struktur dalam basis data baik dalam penambahan objek baru (table) atau dengan penambahan kolom - kolom pada suatu tabel.

6. Keamanan (Security)

Keamanan untuk menentukan user yang boleh menggunakan basis data beserta objek-objek didalamnya dan menentukan jenis-jenis operasi apa saja yang boleh dilakukan user.

7. Kebersamaan pemakai (Sharability)

Pemakai basis data seringkali tidak terbatas pada satu pemakai saja di satu lokasi atau satu sistem aplikasi saja. Data pegawai dalam basis data kepegawaian, misalkan dapat digunakan oleh banyak sistem (sistem penggajian, sistem akuntansi, sistem inventori, dan lain-lain). Basis data yang dikelola oleh sistem aplikasi yang mendukung lingkungan multiuser, akan dapat memenuhi kebutuhan ini, tapi tetap dengan menjaga atau menghindari munculnya persoalan baru seperti inkonsonsestensi data (karena data yang sama diubah oleh banyak pemakai disaat yang bersamaan) atau kondisi deadlock (karena ada banyak pemakai yang saling menunggu untuk menggunakan data).

\subsubsection{Penyusunan Sistem Basis Data}

Pengertian sistem basis data adalah sekelompok basis data dalam suatu sistem yang mungkin tidak ada hubungan antara yang satu dengan yang lain tetapi secara umum ada hubungan sistem. Jadi ruang lingkupnya lebih luas dibanding basis data. Kemudian database didefinisikan sebagai kumpulan file-file yang saling berelasi, relasi tersebut biasa ditunjukan 
dengan kunci dari tiap file yang saling berhubungan untuk menunjukan satu kumpulan data yang dipakai dalam satu lingkup instansi dengan pengertian yang lengkap dan dapat direkam kedalam satu record.

Definisi database yang akan dibutuhkan dan penyusunan database tersebut adalah:

1. Entity adalah orang, tempat, kejadian atau konsep yang informasinya direkam.

2. Atribut adalah item data yang menjadi bagian dari suatu entitas. Atribut juga disebut sebagai data elemen, data field dan data item.

3. Data value adalah data aktual atau informasi yang disimpan pada tiap data elemen atau atribut.

4. Record adalah kumpulan elemen-elemen yang saling berkaitan dan menginformasikan tentang suatu entity secara lengkap.

5. File yaitu kumpulan record-record sejenis yang mempunyai panjang elemen yang sama. Atribut yang sama, namun berbeda valuenya.

6. Database adalah kumpulan file-file yang mempunayai kaitan antara satu file dengan file yang lain sehingga membentuk satu data untuk menginformasikan keinstansi dalam batasan tertentu.

7. DBMS, Kumpulan file yang saling berhubungan atau bersama dengan program untuk pengolahannya disebut dengan Database Managemen System.

\subsection{Tinjauan Perangkat Lunak \\ 2.4.1 Appserv}

Appserv salah satu Server Web dalam membangun Website. Appserv adalah sebuah aplikasi Web server lokal yang terdiri dari Apache, My SQL, PHP, dan PHP My Admin. Appserv merupakan sebuah aplikasi open source yang mendukung sebagai aplikasi untuk dijadikan Web Server. Appserv merupakan Web server yang mudah di gunakan yang dapat melayani halaman dinamis. Untuk membangun sebuah Web server, salah satu program yang handal dan gratis yang penulis gunakan dalam membuat tugas akhir ini adalah Appserv-win32-
8.5.0. exe. Menurut Yuhendra, M.T, Dr. Eng (2015).

\subsubsection{PHP}

PHP adalah bahasa yang dirancang secara khusus untuk penggunaan pada Web. PHP adalah tool untuk pembuatan halaman web dinamis. Pada awalnya PHP merupakan kependekan dari Personal Home Page (Situs Personal). PHP pertama kali dibuat oleh Rasmus Lerdorf pada tahun 1995. Pada waktu itu PHP masih bernama FI (Form Interpreted), yang wujudnya berupa sekumpulan script yang digunakan untuk mengolah data form dari web. Saat ini PHP adalah singkatan dari PHP:Hypertext Preprocessor, sebuah kepanjangan rekursif, yakni permainan kata dimana kepanjangannya terdiri dari singkatan itu sendiri: PHP: Hypertext Preprocessor. Menurut Akhmad Sholikhin (2013).

\subsubsection{MySQL}

MySQL adalah salah satu aplikasi DBMS (Database Management System) yang sudah sangat banyak digunakan oleh para pemrogram aplikasi web. Dalam sistem database tak relasional, semua informasi disimpan pada satu bidang luas, yang kadangkala data di dalamnya sangat sulit dan melelahkan untuk diakses. Tetapi MySQL merupakan sebuah sistem database relasional, sehingga dapat mengelompokkan informasi ke dalam tabel-tabel atau grup-grup informasi yang berkaitan. Setiap tabel memuat bidang-bidang yang terpisah, yang mempresentasikan setiap bit informasi. MySQL menggunakan indeks untuk mempercepat proses pencarian terhadap baris informasi tertentu. MySQL memerlukan sedikitnya satu indeks pada tiap tabel. Biasanya akan menggunakan suatu primary key atau pengenal unik untuk membantu penjejakan data. Menurut Ibrahimy Situbondo (2017).

\subsection{Perancangan Sistem}

Menurut Muchamad Shodiq, Sistem informasi yang baik tidak lepas dari sebuah perancangan yang matang dan terstruktur. Layaknya membuat sebuah bangunan, tentulah dibutuhkan sebuah blueprint supaya bangunan tersebut dapat tepat sasaran dan tepat guna. Oleh karena itu, dalam penelitian aplikasi tugas akhir ini, penulis menggunakan metode waterfall. Metode ini terdiri dari beberapa tahap yaitu analisa kebutuhan (requirements), analisa 
(analysis), desain (design), implementasi (implementation) dan pengujian (testing).

\section{Analisa Kebutuhan}

Pada analisis kebutuhan bertujuan untuk mengumpulkan kebutuhan-kebutuhan pengguna dan kemudian mentransformasikan ke dalam sebuah deskripsi yang jelas dan lengkap.

2. Analisa Sistem

Tahap analisis sistem bertujuan untuk menjabarkan segala sesuatu yang nantinya akan ditangani oleh perangkat lunak. Tahapan ini berisi analisa dari permasalahan yang ada pada tahap sebelumnya, meliputi aktor yang terlibat dalam sistem, kebutuhan fungsional dan kebutuhan aplikasi yang muncul berdasarkan kendala yang ada.

\section{Rancangan / Desain}

Tahap perancangan perangkat lunak (design) merupakan proses yang berfokus pada beberapa atribut yang ada di perangkat lunak. Proses ini menerjemahkan kebutuhan ke dalam sebuah model perangkat lunak dan berdasarkan analisis sistem sebelumnya menghasilkan rancangan yang berisi ERD (Entity Relationship Diagram), UML, dan desain antar muka.

\section{Implemtasi dan Pengujian}

Merupakan tahap mengkonversi apa yang telah dirancang sebelumnya ke dalam sebuah bahasa yang dimengerti komputer. Tahap ini dibagi menjadi implementasi program dan implementasi deployment.

\section{Pengujian}

Proses pengujian menggunakan metode black box dibagi menurut fungsi dari masing-masing menu sesuai dengan kegunaannya.

\section{METODE PENELITIAN}

\subsection{Metode Pengumpulan Data}

\subsection{Metode Pengumpulan Data}

Untuk membangun Analisis Dan

Perancangan Sistem Informasi Seleksi

Penerimaan Beasiswa PTN Siswa/i Labuhanbatu Berbasis Web sebagai objek penelitian dalam tugas akhir ini, maka dilakukan pengumpulan data yang menjadi kebutuhan sistem yang akan dibangun melalui beberapa kegiatan seperti observasi, Wawancara (interview) dan studi kepustakaan. Setelah itu dilakukan analisis terhadap sistem yang berjalan agar sistem yang dibangun sesuai dengan prosedur di Kantor Kesra Setdakab Labuhanbatu.

\subsubsection{Teknik Pengumpulan Data}

Teknik pengumpulan data adalah cara-cara yang dilakukan dalam mendapatkan data yang dibutuhkan didalam penyusunan laporan tugas akhir ini.

Dalam melakukan penelitian ini, penulis melakukan pengumpulan data dengan cara sebagai berikut:

1. Metode Observasi

Suatu metode pengumpulan data dengan cara mengamati secara langsung proses pendataan di ambil dari Kantor Kesra Setdakab Labuhanbatu.

2. Metode Wawancara

Yaitu melakukan Tanya jawab langsung kepada pimpinan mau pun karyawan intansi sehingga mendapat data yang di butuhkan. Ada pun alat yang di gunakan adalah alat tulis seperti pena, pensil dan buku.

3. Metode Kepustakaan

Melakukan pengkajian data dengan cara mengumpulkan dan membaca buku, majalah, serta tulisan-tulisan ilmiah yang berkaitan dengan penulisan tugas akhir ini, terutama yang berhubungan dengan masalah seleksi penerimaan beasiswa di Kantor Ksera Setdakab Labuhanbatu.

\section{Rancangan Interface}

Rancangan Interface adalah rancangan awal sistem informasi yang menjadi antar muka antar pengguna sistem informasi dengan sistem yang akan dipakai. Dengan kata lain interface adalah program yang menjembata antar pemakai sistem informasi untuk masuk ke dalam sistem informasi.

Rancangan antar muka ini bertujuan untuk memberikan interface tentang desain program yang akan dibuat. Dibawah ini terdapat desain pada tampilan yang akan dibuat

1. Menu Utama. 


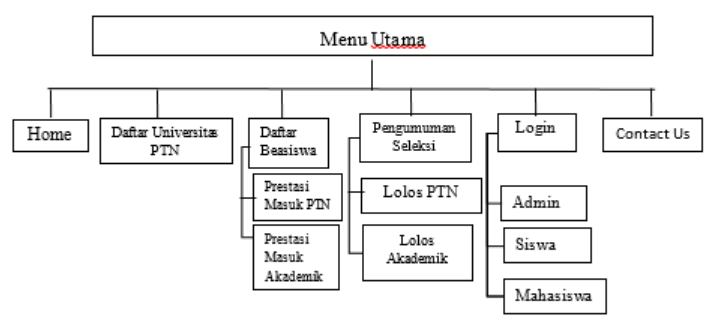

\section{Gambar 3.1 Perancangan Interface Menu Utama}

\section{HASIL DAN PEMBAHASAN}

\section{1 Hasil}

Hasil dari perancangan intrerface merupakan tahap untuk memudahkan admin dalam menggunakan sistem yang baru dan perancangan ini harus sesuai dengan kebutuhan Instansi. Berikut rancangan interface dari form dan report sistem yang baru :

\section{1.1 Form Menu Login Admin}

Untuk bisa mengakses ke menu admin, user harus mengisi dengan benar terlebih dahulu username dan password di form Login. Di lihat pada gambar 4.1

\section{Login Admin $\rightarrow$ ]}

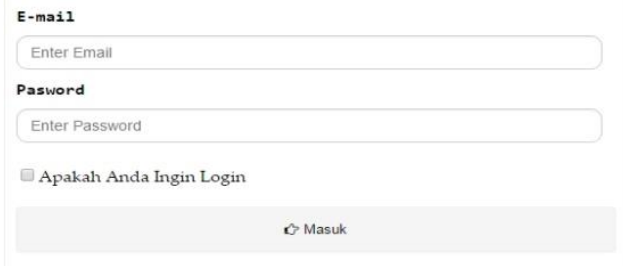

\section{Gambar 4.1 Form Menu Login Admin}

\subsubsection{Halaman Utama}

Tampilan Halaman utama merupakan halaman yang menampung menu -menu utama sistem, dapat di lihat pada gambar 4.2. berikut.

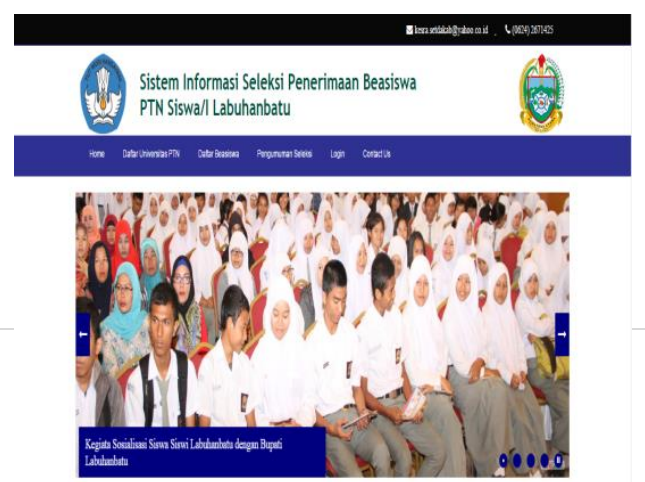

\section{Gambar 4.2 Desain Halaman Utama}

\subsubsection{Menu Bar}

Pada menu Bar terdapat submenu yang aktif yaitu Home, Daftar Universitas PTN, Daftar Beasiswa, Pengumuman Seleksi, Login, dan Contact Us.

1. Submenu Daftar Beasiswa berfungsi untuk membuat dan mengakses akun siswa dan mahasiswa agar dapat mendaftar dengan mudah dengan memiliki akun masing-masingnya.

2. Submenu login akan menampilkan form login admin, siswa, dan mahasiswa kemudian jika pengguna sukses pengguna dapat menggunakan sistem sesuai hak aksesnya.

3. Submenu Pengumuman seleksi akan menampilkan siswa dan mahasiswa yang lolos seleksi beasiswa PTN maupun Akademik.

\subsubsection{Menu Daftar Beasiswa}

Menu Daftar beasiswa adalah Berisi tentang pendaftaran beasiswa ptn dan akademik dapat di lihat pada gambar 4.3 sebagai berikut.

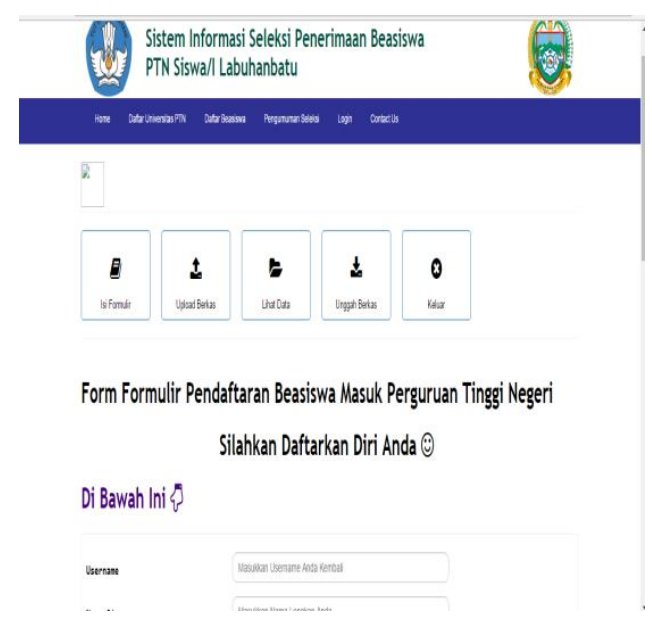

Gambar 4.3 Menu Daftar Beasiswa

1. Daftar Prestasi masuk PTN 
Daftar prestasi masuk PTN merupakan pendaftaran siswa jika ingin mendaftar harus membuat akan terlebih dahulu.

ra
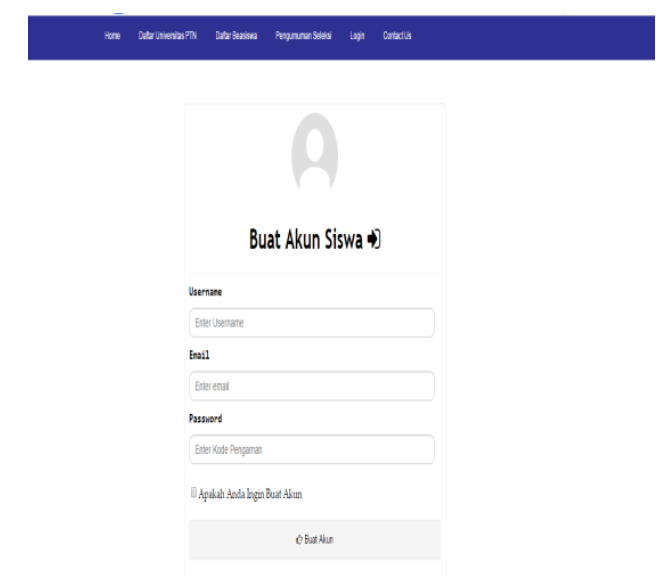

\section{Gamabar 4.4 Form Daftar Prestasi PTN}

2. Daftar Prestasi Akademik

Daftar prestasi masuk Akademik merupakan pendaftaran mahasiswa yang mendaftar harus membuat akan terlebih dahulu.
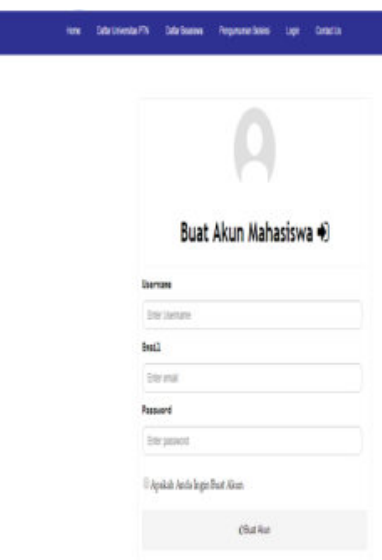

\section{Gambar 4.5 Form Daftar Prestasi Akademik}

1. Form Fomulir Pendaftaran Beasiswa

Form formulir ini merupakan form pendaftaran beasiswa bagi pendaftar siswa PTN.

\section{Form Upload Berkas}

Form ini merupakan form upload berkas beasiswa bagi pendaftar siswa PTN.

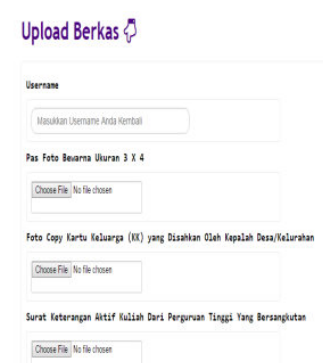

\section{Gambar 4.5 Form Upload berkas Pendafatar Beasiswa}

3. Form Lihat data Pendaftar

Form ini merupakan form data yang telah di inputkan beasiswa bagi pendaftar siswa PTN.

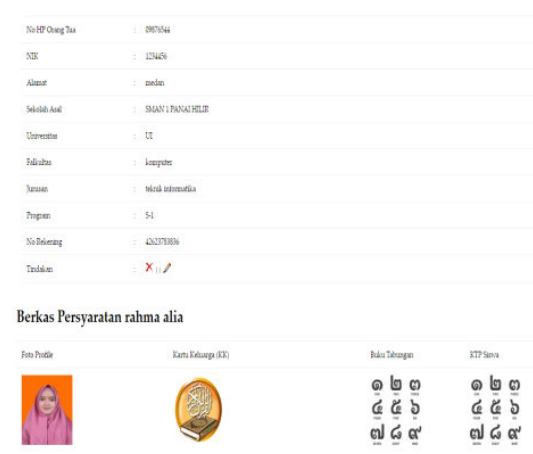

\section{Gambar 4.5 Form data Pendaftar Beasiswa}

\subsubsection{Form Halaman Admin}

Form ini merupakan sebagai penyeleksi data siswa dan mahasiswa yang telah mendaftar dan akan disimpan dan di seleksi sebagai Laporan Lolos seleksi. Dapat di lihat pada gambar 4.6 sebagai berikut.

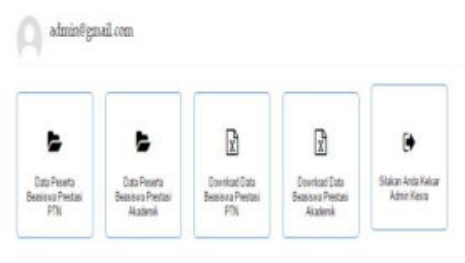

Dat Siswa Yang Mendaftar Penerimaun Buesiswa Prestasi Lolos PIN

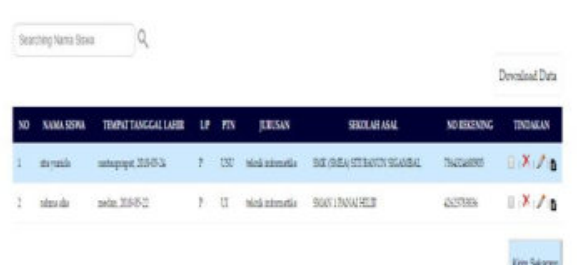

Gambar 4.6 Data Pendaftar Beasiswa

\subsubsection{Menu Pengumuman Seleksi}


Menu pengumuman Seleksi merupakan daftar nama Pendaftar Yang Lolos seleksi Beasiswa PTN maupun akademik dan terdapat sebuah laporan jika di klik link Download Berkas

\section{Lolos PTN}

Halaman ini adalah daftar nama siswa/i Labuhanbatu yang lolos Beasiswa PTN setelah lolos seleksi.

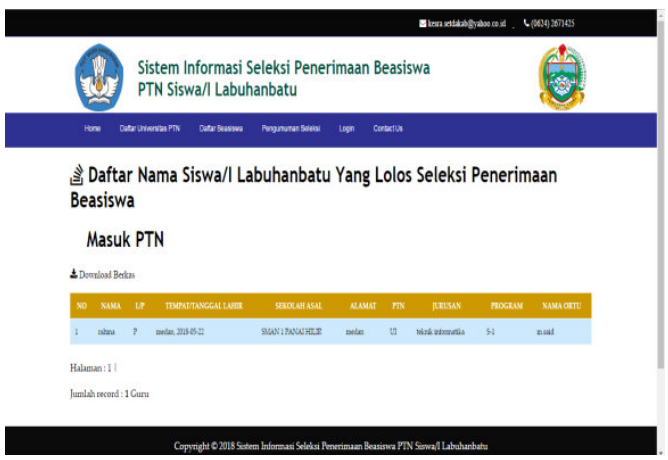

Gambar 4.7 Data Lolos PTN

2. Lolos Akademik

Halaman ini adalah daftar nama siswa/i Labuhanbatu yang lolos Beasiswa Akademik setelah lolos seleksi.

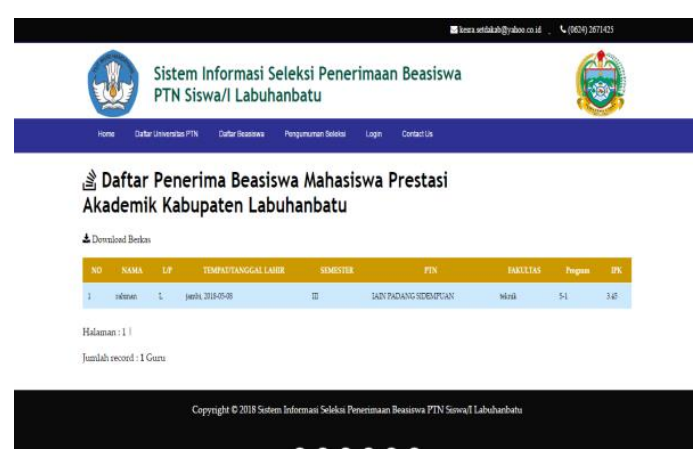

Gambar 4.8 Data Lolos Akademik

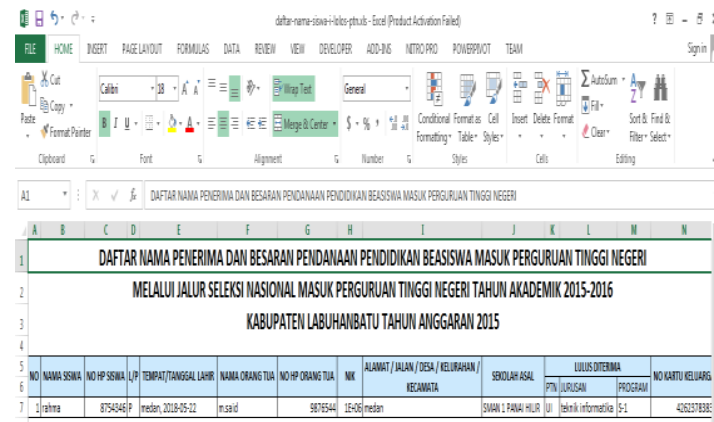

Gambar 4.9 Laporan Data Lolos PTN

\subsubsection{Laporan}

Laporan adalah lintasan untuk melihat data setelah di download.

\section{Data PTN}

Laporan Data Yang Lolos Seleksi Penerimaan Beasiswa PTN.

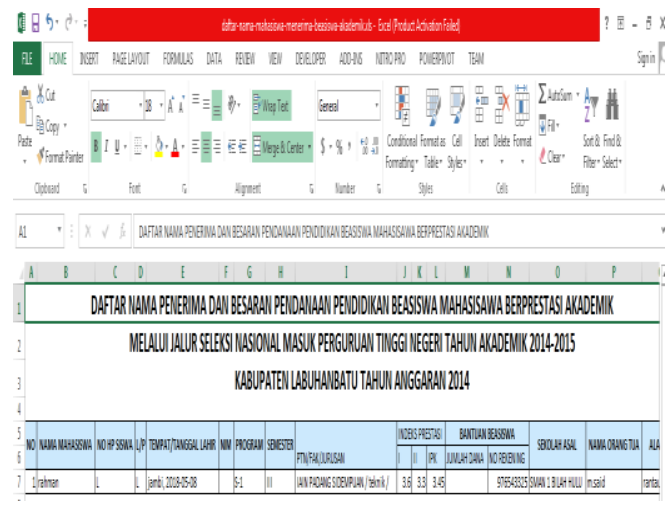

Gambar 4.10 Laporan Data Lolos Akademik

2. Data Akademik Laporan Data Yang Lolos Seleksi Penerimaan Beasiswa Akademik. 


\section{2 Pembahasan}

\section{2.1 Prosedur Kerja Sistem}

Prosedur kerja sistem yang telah dibuat merupakan data beasiswa dan penentuan dari sistem yang sedang berjalan atau sistem yang lama untuk mempermudah dalam pendefenisian permasalahan atau kendala - kendala yang terjadi pada Perancangan Sistem Informasi Seleksi Penerimaan Beasiswa dengan tujuan untuk memperoleh desain sistem baru. Sebelum melakukan perancangan sistem maka dilakukan peninjauan terlebih dahulu terhadap sistem yang sedang berjalan pada saat ini, sistem yang berjalan penting untuk dianalisa karena merupakan dasar untuk merencanakan sistem yang baru dimana sistem yang lama dijadikan sebagai perbandingan untuk merancang sistem yang baru. Adapun tujuan dari analisa sistem ini adalah sebagai berikut :

1. Untuk membuat suatu Sistem basis data mengenai Seleksi Penerimaan Beasiswa PTN Siswa/i Labuhanbatu Berbasis Web.

2. Untuk mengembangkan serta memperbarui sistem pemprosesan data Beasiswa PTN Siswa/i Labuhanbatu.

3. Membuat suatu basis data dengan sistem informasi yang dapat membatu Kantor Kesra Setdakab Labuhanbatu.

4. Memenuhi salah satu syarat untuk menyelesaikan pendidikan Diploma III pada Program Studi Manajemen Komputer AMIK Labuhanbatu.

\subsubsection{Spesifikasi Kebutuhan Sistem}

Pembuatan program dibuat sesuai dengan sistem yang telah dirancang, dimana pada sistem yang dirancang menggunakan sistem komputerisasi. Siste $m$ Informasi Seleksi Penerimaan Beasiswa PTN Siswa/i Labuhanbatu menggunakan perangkat pendukung, seperti software maupun hardware diantaranya:

\section{PHP (Hypertext Prototype)}

Bahasa Pemograman ini dipergunakan dalam pembuatan sistem komputerasi karena sarana akses data yang lebih cepat dan andal untuk membuat program database yang berkemampuan tinggi serta memiliki compiler andal yang dapat menghasilkan file executable yang lebih cepat dan efesien dari sistem sebelumnya.

\section{Mysql}

Software ini digunakan dalam membuat database yang akan menampung data sistem inventory. Alasan kenapa penulis memilih software ini karena dalam perancangan, membuat dan mengolah database-nya sangat mudah dan prosesnya cepat serta didukung oleh sistem keamanan yang tinggi sehingga mencegah pihak lain untuk merusak atau membuka database tersebut.

\section{Spesifikasi Hardware}

Sistem informasi yang telah terkomputerisasi ini dapat dijalankan apabila telah dilakukan beberapa hal, yaitu proses instalasi sudah dilakukan serta hardware yang mendukung dalam menjalankan program ini. Spesifikasi hardware yang dibutuhkan untuk mengimplementasikan sistem agar dapat berjalan dengan baik adalah sebagai berikut :

- Komputer dengan processor mulai dari Intel Pentium III.

- Memory 2 GB DDR3 PC10600

- Harddisk $20 \mathrm{~Gb}$.

- VGA card $32 \mathrm{Mb}$ dengan SVGA Monitor.

- Printer dengan tipe Cannon iP2700

- Mouse dan Keyboard

\subsubsection{Kelebihan Sistem}

1. Dengan menggunakan program PHP, Perancangan Sistem Informasi Seleksi Penerimaan Beasiswa ini dapat secara langsung menginputkan data yang diperlukan tanpa harus melakukan pencatatan melalui pembukuan.

2. Dengan menggunakan program PHP, Sistem Informasi Seleksi Penerimaan Beasiswa ini dapat membuat laporan dari hasil penginputan data-data yang baru diinputkan, dimana data sudah tersimpan dalam database sehingga dapat dicetak langsung.

\subsubsection{Kelemahan Sistem}

1. Apabila dilakukan pemindahan sistem ke komputer lain, sistem tidak dapat secara otomatis melakukan running ke komputer baru.

2. Aplikasi masih dilakukan dalam bentuk folder Web belum menjadi software.

3. Kekurangan dalam penjumlah nilai IPK.

4. Keterbatasan dalam penggunaan sistem, dimana ketika terjadi penambahan atau 
perubahan, maka operator harus merefresh sistem yang dibuat, dan merefresh laporan baru yang diinputkan.

\subsubsection{Software}

Perangkat lunak yang diperlukan dalam pembuatan sistem dan pemrosesan data dari sistem yang dihasilkan adalah

1. Microsoft Windows 7 sebagai sistem operasi

2. Aptana Studio 3

3. MySQL Server sebagai program DBMS

4. Appserv 2.4.23 sebagai penyedia server localhost

\section{KESIMPULAN DAN SARAN \\ 5.1 Kesimpulan}

Setelah berhasil merancang dan membuat Sistem Informasi Seleksi Penerimaan Beasiswa PTN Siswa/i Labuhanbatu, penulis mendapat banyak hal-hal yang bermanfaat. Dengan begitu penulis dapat menyimpulkan beberapa hal, diantaranya :

1. Berdasarkan hasil penerapan sistem pada Kantor Kesra Setdakab Labuhanbatu, sistem yang dihasilkan dapat membantu dalam mengatasi permasalah pada sistem yang lama dimana penggunaannya memakan waktu yang lama dan dengan dukungan sistem ini akan lebih cepat dan akurat untuk mendapatkan informasi.

2. Dengan aplikasi yang dirancang pada program Sistem Seleksi Penerimaan Beasiswa PTN ini maka akan mempermudah dalam penginputan data-data yang sifatnya baru.

Pengolahan data pada sistem informasi Seleksi Penerimaan Beasiswa PTN menghasilkan laporan data Lolos Seleksi Beasiswa.

\subsection{Saran}

Beberapa saran yang dapat diberikan penulis berkenaan dengan pengembangan aplikasi dimasa yang akan datang adalah :

1. Penulis berharap agar sistem dapat dikembangkan lagi, dan program menjadi sempurna lagi dan lebih luas cakupan ruang lingkup programnya.

2. Pengembangan sistem lebih lanjut diharapkan agar sistem dapat dikembangkan untuk sistem informasi Seleksi Penerimaan Beasiswa PTN.
3. Administrator dan petugas sebaiknya menyimpan password dengan baik agar tidak terjadi manipulasi data oleh pihak yang tidak berhak mengakses perangkat lunak ini.

4. Hasil rancangan ini di harapkan menjadi acuan untuk pengembangan sistem informasi kearah yang lebih baik.dimana sistem hanya terbatas kepada pemberian data.

\section{DAFTAR PUSTAKA}

Akbar, M. K. (n.d.). Sistem Informasi Manajemen Pada Rumah Sakit Khusus Paru-Paru Palembang, 2015, 1-8.

Diponegoro, D. I. U. (2013). Simbes, aplikasi manajemen beasiswa di universitas diponegoro berbasis framework code igniter dan mysql.

Hendrawan, V. Y., Winardi, S., Surbakti, H., \& Sains, F. (2014). Sistem Informasi Rekam Medis Rawat Jalan dan Pemriksaan Penunjang Diagnosa Berbasis Website (Studi Kasus : Rumah Sakit Khusus Bedah Klinik Sinduadi, MLATI, Sleman, Yogyakarta), 9, 53-58.

Jurnal, I. (2013). Pembangunan Sistem Informasi Inventarisasi Sekolah Pada Dinas Pendidikan Kabupaten Rembang Berbasis Web, 2(2), 50-57.

Komtekinfo, J., Ilmu, F., Pendahuluan, I., Nasional, P., \& Barat, S. (2015). Implementasi Metode Pwngkodean Komputasi Katalog Buku Diperpustakaan Nasional Sumatera Barat Dengan Menggunakan Bahasa Pemograman PHP dan Database MYSQL, 2(1), 99-105.

Lutfi, A. (2017). Sistem Informasi Akademik Madrasah Aliyah Salafiyah Syafi'iyah Menggunakan PHP dan MYSQL, 3(2), 104-112.

Perancangan Sistem Pembelajaran E-Learning Berbasis Moodle CMS (Content Management System) Pada LPK - Sigma Tangerang. (2017), 5(2), 126-144.

Sidik, A., Sakuroh, L., \& Dariatno, D. (2015). Sistem Pendukung Keputusan Pemberian 
Beasiswa Untuk Menentukan Mahasiswa Berprestasi Berbasis Web Dengan Metode AHP, 5(2), 1-7.

Supratman, E., Kom, M., \& Binadarma, D. U. (2017). Sistem Informasi Kelurahan Alang-alang Lebar Kecamatan Alangalang Lebar Palembang Berbasis Web, $3(2)$.

Yulianto, R. E. (2015). Rekayasa Perangkat Lunak Pengolahan Data Distribusi Obatobatan di Pt. Anugrah Pharmindo Lestari Berbasis Web, 17(2). 